JOTE Volume 2 Nomor 1 Tahun 2020 Halaman 262-269 JOURNAL ON TEACHER EDUCATION

Research \& Learning in Faculty of Education

\title{
Penerapan Model Pembelajaran Kooperatif Tipe Paired Story Telling untuk Meningkatkan Keterampilan Menulis karangan Narasi Peserta Didik Sekolah Dasar
}

\author{
Siska Mardhotillah', Yenni Fitra Surya², Zulfah ${ }^{3}$ \\ S1 PGSD, Fakultas IImu Pendidikan, Universitas Pahlawan Tuanku Tambusai \\ siskamardhotillah00@gmail.com
}

\begin{abstract}
Abstrak
Tujuan penelitian ini untuk mendeskripsikan peningkatan keterampilan menulis karangan narasi dengan menggunakan model Paired Story Telling pada peserta didik kelas V SD Negeri 002 Pasir Sialang. Metode penelitian ini adalah penelitian tindakan kelas (PTK) yang dilaksanakan dalam dua siklus. Setiap siklus terdiri dari dua pertemuan dan empat tahap. Subjek penelitian ini peserta didik kelas $\mathrm{V}$ yang berjumlah 16 orang, dengan jumlah peserta didik laki-laki 6 orang dan peserta didik perempuan berjumlah 10 orang. Hasil penelitian ini disimpulkan bahwa keterampilan menulis karangan narasi peserta didik kelas $\mathrm{V}$ SDN 002 Pasir Sialang pada siklus I tergolong rendah dengan rata-rata 69,2. Selanjutnya dari 16 orang peserta didik hanya 8 orang yang tuntas, sedangkan ketuntasan belajar klasikal $50 \%$. Pada siklus II sudah baik, dengan rata-rata 78 , dan dari 16 orang peserta didik terdapat 12 orang peserta didik yang tuntas, sedangkan ketuntasan belajar klasikal $75 \%$.
\end{abstract}

Kata kunci: Karangan Narasi, Paired Story Telling.

\section{Abstract}

The purpose of this study was to describe the improvement of narrative essay writing skills using the Paired Story Telling model for fifth grade students of SD Negeri 002 Pasir Sialang. This research method is a classroom action research (PTK) which is carried out in two cycles. Each cycle consists of two meetings and four stages. The subjects of this study were 16 grade $V$ students, 6 male students and 10 female students. The results of this study concluded that the skills of writing narrative essays of the fifth grade students of SDN 002 Pasir Sialang in the first cycle were classified as low with an average of 69.2. Furthermore, from the 16 students only 8 completed, while the classical learning completeness was $50 \%$. In cycle II it was good, with an average of 78 , and of the 16 students there were 12 students who completed, while classical learning completeness was $75 \%$.

Keywords: Narrative Composition, Paired Story Telling. 


\section{PENDAHULUAN}

Keterampilan berbahasa berhubungan erat dengan cara yang beraneka ragam. Menguasai keterampilan berbahasa, harus dibutuhkan latihan yang intensif. Hal ini sejalan dengan pernyataan Tarigan (2013) bahwa keterampilan menulis tidak akan datang secara otomatis, tetapi harus melalui latihan dan praktik yang banyak dan teratur.

Iskandarwassid dan Dadang Sunendar (2009:248) mengemukakan, aktivitas menulis merupakan suatu bentuk manifestasi kemampuan dan keterampilan berbahasa yang terakhir dikuasai oleh peserta didik setelah kemampuan mendengarkan, berbicara dan membaca. Keterampilan menulis mempunyai peranan sangat penting dalam kehidupan manusia, dengan menulis seseorang dapat mengungkapkan pikiran, ide, dan gagasan untuk mencapai maksud dan tujuannya. Selama ini masyarakat menilai pelajaran Bahasa Indonesia disekolah kurang menunjukkan hasil yang memuaskan dan masih jauh dari harapan.

Menulis merupakan sebuah proses kreatif menuangkan gagasan dalam bentuk bahasa tulis dalam tujuan, misalnya memberitahu, meyakinkan atau menghibur. Hasil dari proses kreatif ini biasa disebut dengan istilah karangan atau tulisan. Kedua istilah tersebut mengacu pada hasil yang sama meskipun ada pendapat yang mengatakan kedua istilah tersebut mempunyai pendapat yang berbeda. Istilah menulis sering dilekatkan pada proses keratif yang berjenis nonilmiah, Dalman (2011).

Menulis merupakan salah satu keterampilan yang mempunyai peranan penting dalam kehidupan sebab dengan menulis, seseorang dapat berkomunikasi secara tidak langsung, dalam arti tidak secara bertatap muka dengan orang lain, dengan menulis seseorang dapat merekam segala peristiwa, pendapat, dan sebagai penyalur informasi dalam bentuk tulisan. Salah satu kompetensi menulis yang harus dikuasai peserta didik di kelas adalah menulis karangan narasi.

Pembelajaran menulis di SD antara lain mempelajari tentang pengalaman huruf, ejaan, pengembangan ide atau gagasan, membuat surat pribadi, dan pengembangan menyusun karangan. Demikian halnya dengan peserta didik kelas V SD, pada fokus pembelajaran bahasa Indonesia mereka mendapatkan materi tentang menulis. Adapun pembelajaran menulis pada peserta didik kelas $\mathrm{V}$ SD salah satunya membahas tentang menulis karangan berdasarkan pengalaman (menulis narasi). Sebagai salah satu materi pembelajaran, maka pembelajaran menulis tersebut perlu disampaikan dengan metode yang tepat sehingga mencapai standar kompetensi yang diharapkan yaitu peserta didik mampu mengungkapkan pikiran, perasaan, informasi, dan pengalaman secara tertulis dalam bentuk karangan.

Berdasarkan hasil observasi yang telah dilakukan, ditemukan permasalahan yaitu keterampilan menulis karangan narasi peserta didik yang masih tergolong rendah. Hal ini berdasarkan dari nilai rata-rata kelas yang hanya mencapai 62. Nilai tersebut lebih kecil dari KKM untuk keterampilan menulis pada mata pelajaran bahasa Indonesia yaitu 75. Dari 16 peserta didik, 5 orang 
peserta didik yang mendapatkan nilai baik atau di atas KKM dan 11 orang peserta didik mendapatkan nilai di bawah KKM. Berikut data peserta didik dapat dilihat pada tabel 1.1 tentang rekapitulasi ketuntasan belajar peserta didik kelas V SDN 002 Pasir Sialang sebagai berikut:

\section{Tabel 1.1}

Rekapitulasi Ketuntasan Belajar Peserta Didik Kelas V SDN 002 Pasir Sialang

\begin{tabular}{|c|c|c|c|}
\hline $\begin{array}{c}\text { Jumlah } \\
\text { Peserta } \\
\text { Didik }\end{array}$ & KKM & $\begin{array}{c}\text { Jumlah Peserta } \\
\text { Didik yang Tidak } \\
\text { Tuntas }\end{array}$ & $\begin{array}{c}\text { Jumlah Peserta Didik } \\
\text { yang Tuntas }\end{array}$ \\
\hline 16 & 75 & $11(68,75 \%)$ & $5(31,25 \%)$ \\
\hline
\end{tabular}

Sumber: Data Primer.

Rendahnya keterampilan menulis karangan narasi pada peserta didik tersebut disebabkan oleh beberapa faktor: 1) metode pembelajaran yang diterapkan guru selama ini cenderung konvensional, 2) peserta didik kurang terampil untuk menemukan ide dan gagasannya, 3) peserta didik kesulitan menuangkan idenya kedalam bentuk tulisan dengan mnggunakan bahasa Indonesia yang baik dan benar, 4) pemilihan kata atau diksi yang kurang tepat, 5) peserta didik belum maksimal kurang mampu menentukan topik dan mengembangkan paragraf.

Ada banyak sekali tipe-tipe model cooperative learning ini dan penulis tertarik menggunakan model kooperatif tipe Paired Story Telling. Lie (2014:71), mengemukakan bahwa "Paired Story Telling merupakan model mengajar bercerita berpasangan yang dikembangkan sebagai pendekatan interaktif antara peserta didik, pengajar, dan bahan ajar". Isjoni (2014: 80), mengemukakan bahwa "bercerita berpasangan (Paired Story Telling) dapat digunakan dalam pengajaran membaca, menulis, mendengarkan, ataupun bercerita yang dikembangkan sebagai interaktif antara peserta didik, pengajar, dan bahan pengajaran". Model ini mengharuskan guru memperhatikan skemata atau latar belakang pengalaman peserta didik dan membantu peserta didik mengaktifkan skemata itu agar bahan pengajaran menjadi lebih bermakna. Kegiatan ini peserta didik dirangsang untuk mengembangkan kemampuan berpikir dan berimajinasi sehingga peserta didik terdorong untuk belajar. Selain itu, peserta didik bekerja dengan sesama peserta didik dalam suasana gotong royong dan mempunyai banyak kesempatan mengolah informasi dan meningkatkan keterampilan berkomunikasi.

Peserta didik dirangsang untuk mengembangkan kemampuan berfikir dan berimajinasi. Buah pemikiran mereka akan dihargai sehingga peserta didik akan terdorong untuk terus belajar. Menurut Isjoni (2013:114), "Paired Story Telling dikembangkan sebagai pendekatan interaktif antara peserta didik, pengajar, dan bahan pengajaran". Lie (2014: 71), mengemukakan bahwa "model Paired Story Telling ini bisa digunakan dalam pengajaran membaca, menulis, mendengarkan, ataupun berbicara. Bahan pelajaran yang paling cocok digunakan dengan model ini adalah bahan yang bersifat naratif dan deskriptif". Namun hal ini tidak menutup kemungkinan dipakainya bahan-bahan yang lainnya. Kegiatan 
pembelajaran dengan menggunakan model Paired Story Telling, peserta didik dirangsang untuk mengembangkan kemampuan berfikir dan hasil dan hasil pemikiran mereka akan dihargai sehingga siswa merasa semakin terdorong untuk belajar. Huda (2015: 151), juga menjelaskan bahwa "dalam proses pembelajaran kooperatif tipe Paired Story Telling peserta didik bekerja dengan sesama peserta didik dalam suasana gotong royong dan mempunyai banyak kesempatan untuk mengolah berbagai macam informasi dan meningkatkan keterampilan dalam berkomunikasi, dan juga memberikan banyak kesempatan pada peserta didik untuk mengolah informasi dan meningkatkan kemampuan berkomunikasi".

Berdasarkan beberapa pengertian Paired Story Telling yang telah dipaparkan oleh beberapa para ahli, maka penulis dapat menyimpulkan bahwa model pembelajaran Paired Story Telling adalah model pembelajaran yang memberikan kesempatan kepada peserta didik untuk berbagi pikiran dan pengalaman belajarnya kepada teman satu kelompok dengan tujuan memperbaiki kegiatan belajar dan mencapai tujuan dan hasil belajar sesuai dengan yang diharapkan.

\section{METODE}

Penelitian ini dilaksanakan di SD Negeri 002 Pasir Sialang Kecamatan Bangkinang Kabupaten Kampar. Alasan pemilihan sekolah ini karena sekolah ini belum pernah digunakan sebagai obyek penelitian yang sejenis sehingga terhindar dari kemungkinan peneletian ulang. Waktu penelitian ini dilaksanakan pada bulan Agustus s/d September 2020 SDN 002 Pasir Sialang Kecamatan Bangkinang.

Subjek dalam penelitian ini adalah peserta didik di kelas $V$ di SDN 002 Pasir Sialang tahun ajaran 2020/2021 yang berjumlah 16 peserta didik, yang terdiri dari 6 laki-laki dan 10 perempuan. Setelah itu, peneliti juga merujuk guru sebagai informan. Selanjutnya, peneliti juga meminta kesediaan teman sejawat dan kepala sekolah sebagai informan. Metode penelitian ini menggunakan penelitian tindakan kelas (PTK) dengan model pembelajaran Paired Story Telling. Menurut Surya, $Y(2017: 14)$, penelitian tindakan kelas merupakan penelitian yang dilakukan oleh guru di dalam kelasnya sendiri melalui refleksi diri dengan tujuan utama memperbaiki kinerjanya sebagai guru. Penelitian dilakukan dengan jalan merancang, melaksanakan dan merefleksikan tindakan secara kolaboratif dan partisipatif yang bertujuan untuk memperbaiki proses pembelajaran di kelas melalui suatu tindakan dalam suatu siklus (Fadhilaturrahmi, 2017).

Menurut Arikunto (2010: 12), siklus PTK dapat dilihat pada gambar digambarkan 3.2 tentang siklus penelitian tindakan kelas (PTK) sebagai berikut: 


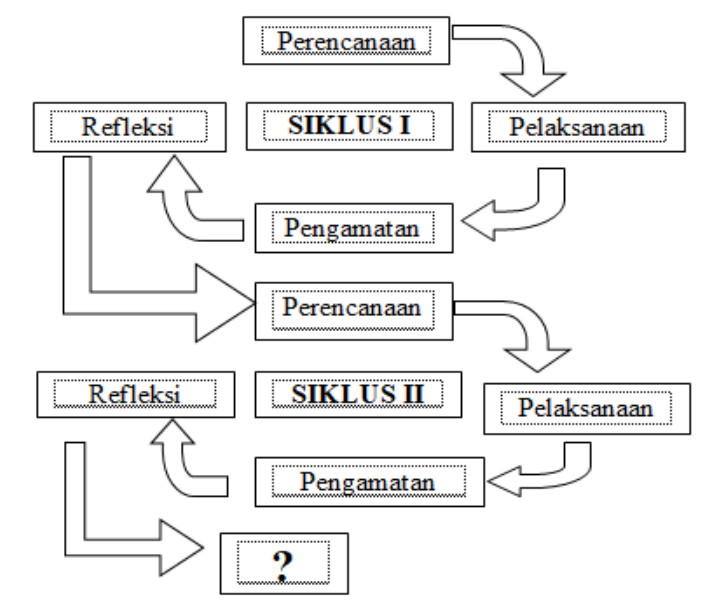

Siklus Penelitian Tindakan Kelas (PTK)

(Arikunto, 2010:12)

\section{PEMBAHASAN}

\section{Pratindakan}

Hasil observasi pengamatan peneliti pada hari Senin, 30 Maret 2020 ketika guru memberikan pelajaran Bahasa Indonesia dengan materi menulis karangan narasi. Peserta didik disuruh membaca contoh teks karangan narasi yang diberikan, kemudian langsung disuruh untuk menulis karangan narasi.

Beberapa peserta didik ada yang kebingungan karena tidak mengetahui apa yang seharusnya ditulis dan dari mana memulai karangannya. Hanya sebagian peserta didik yang langsung mengerjakannya, tetapi kebanyakan peserta didik diam beberapa saat sambil memikirkan apa yang hendak ditulisnya.

Berdasarkan hasil pengamatan peneliti terhadap proses pembelajaran, bahwa rendahnya keterampilan menulis karangan narasi peserta didik disebabkan oleh beberapa faktor yaitu metode pembelajaran yang diterapkan guru selama ini cenderung konvensional, peserta didik kurang terampil menemukan ide dan gagasannya, peserta didik kesulitan menuangkan idenya kedalam bentuk tulisan dengan menggunakan bahasa Indonesia yang baik dan benar, pemilihan kata atau diksi yang kuang tepat, peserta didik kurang mampu menentukan topik dan mengembangkan paragraf.

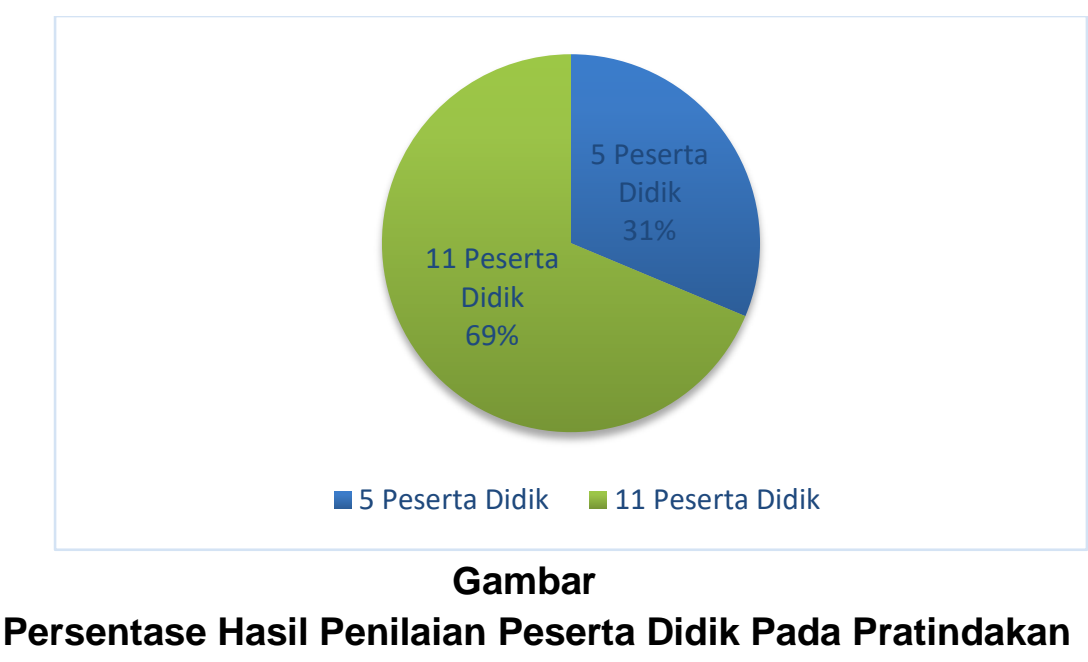


Berdasarkan hasil penilaian di atas, peneliti dan wali kelas berdiskusi untuk mengatasi permasalahan tersebut. Hasil diskusi tersebut, peneliti dan wali kelas sepakat menerapkan model kooperatif tipe Paired Story Telling dalam pembelajaran menulis karangan narasi.

\section{Siklus I}

Sebelum dilaksanakan tindakan, terdapat beberapa hal yang harus dipersiapkan, yaitu: 1) menetapkan jumlah siklus penelitian, 2) menetapkan waktu penelitian, 3) menetapkan materi pelajaran yang akan disajikan, 4) menyusun silabus dan rencana pelaksanaan pembelajaran (RPP), 5) mempersiapkan LTS, 6) menyusun alat evaluasi, 7) menunjuk teman sejawat untuk observer, 8) membuat lembar observasi guru dan peserta didik.

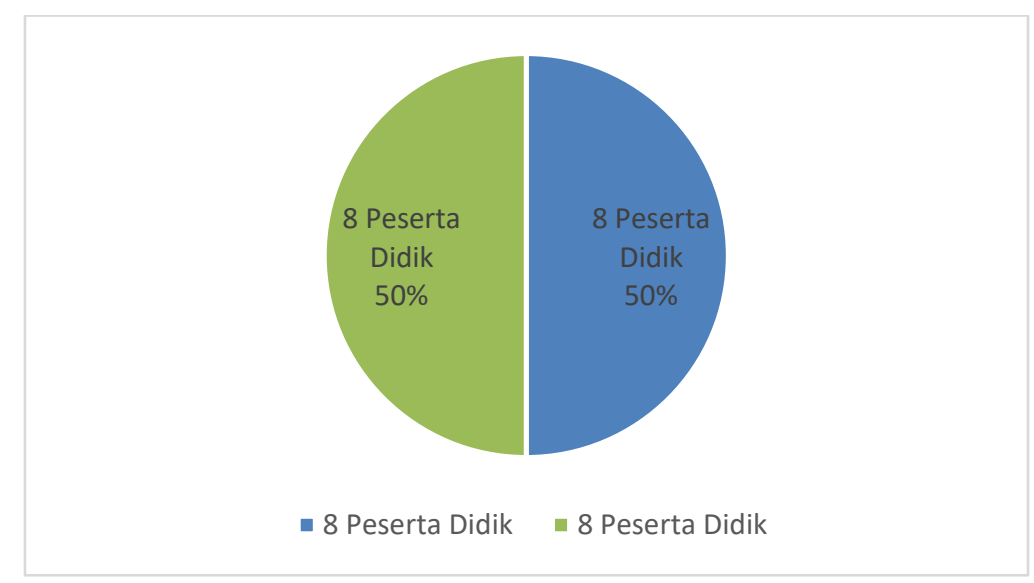

\section{Gambar Nilai Persentase Peserta Didik Siklus I}

Berdasarkan masalah-masalah yang telah disebutkan sebelumnya, peneliti dan guru mengubah tindakan yaitu perubahan anggota kelompok belajar. Anggota kelompok baru yang dibentuk pada siklus II terdiri dari peserta didik lakilaki dan perempuan dengan tingkat intelegensi tinggi, sedang, dan kurang dari hasil belajar siklus I. Pembelajaran pada siklus II dibuat lebih menarik agar peserta didik lebih antusias. Saat pembelajaran secara kelompok untuk mendiskusikan pengalaman mereka terkait dengan tema menulis karangan narasi yang telah ditentukan, seluruh anggota kelompok dilibatkan seluruhnya. Pada proses pembelajaran peneliti lebih menekankan pada aspek menulis kalimat serta ejaan dan tanda baca, dikarenakan banyak peserta didik mengalami kesulitan dalam menuangkan kalimat dan serta ejaan dan tanda baca. Karena hasil siklus I yang belum maksimal, maka penelitian ini dilanjutkan pada siklus II.

\section{Siklus II}

Siklus II dalam penelitian ini terdiri dari 2 pertemuan. Masing-masing pertemuan berlangsung kurang lebih selama 70 menit (2x35 menit) atau 2 jam pelajaran. Pertemuan 1 pada siklus II dilaksanakan pada tanggal 18 Agustus 2020. Prosedur penelitian pada siklus II ini sama dengan prosedur penelitian pada siklus I, yaitu: tahap perencanaan, tahap tindakan dan observasi, serta tahap refleksi. Sebelum dilaksanakan tindakan, terdapat beberapa hal yang harus dipersiapkan oleh peneliti, yaitu perangkat pembelajaran yang terdiri dari silabus, RPP, lembar aktivitas dan soal tes yang telah disusun untuk pertemuan 
1 siklus II, kemudian meminta kesediaan guru kelas $\mathrm{V}$ yaitu Ibu Evi Marianti untuk menjadi observer lembar aktivitas guru (peneliti), dan teman sejawat yaitu Ani Mahyuni untuk menjadi observer aktivitas peserta didik.

Pembelajaran Bahasa Indonesia merupakan pelajaran inti, maka proses pembelajaran dilakukan 2 kali dalam 1 minggu 2 jam pelajaran pada setiap pertemuan. Siklus II terdiri dari 2 pertemuan.

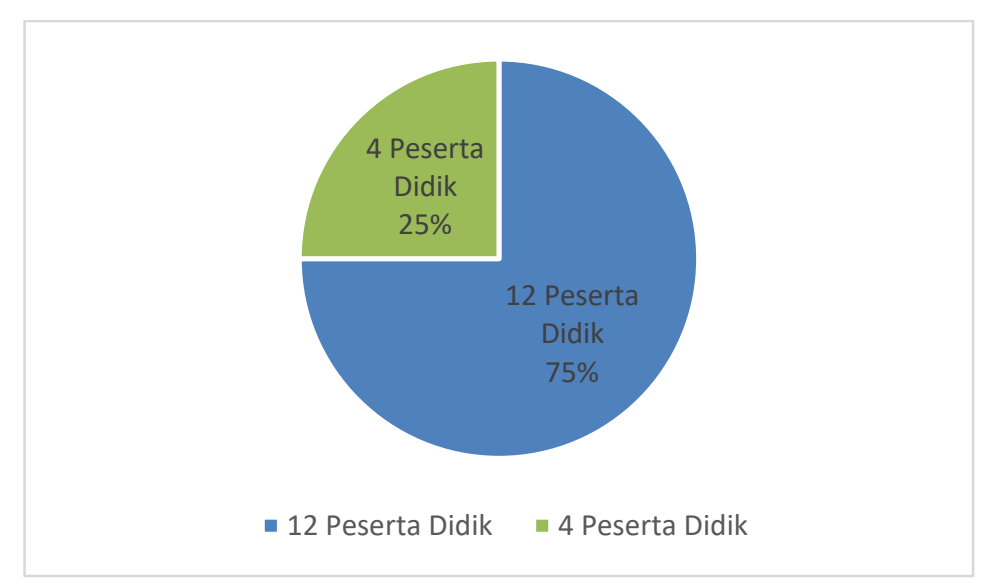

\section{Gambar Nilai Persentase Peserta Didik Siklus II}

Pelaksanaan pembelajaran pada pertemuan kedua siklus II secara umum sudah baik. Berdasarkan hasil evaluasi dan membuat kesimpulan pada siklus II, dapat diketahui bahwa keterampilan menulis karangan narasi peserta didik mengalami peningkatan. Selain itu, dilihat dari hasil observasi peneliti terhadap guru dan peserta didik menunjukkan bahwa proses pembelajaran pun mengalami peningkatan.

Perbaikan pembelajaran menulis karangan narasi melalui model pembelajaran kooperatif tipe Paired Story Telling tersebut telah mencapai tujuan yang diharapkan, yaitu nilai nilai rata-rata menulis karangan narasi peserta didik $\geq 75$ (sekurang-kurangnya $75 \%$ siswa mendapatkan nilai 75 ). Peneliti dan guru sepakat untuk mengakhiri perbaikan pembelajaran dan penelitian tindakan kelas hanya sampai siklus II dan tidak dilanjutkan ke siklus berikutnya.

\section{KESIMPULAN}

Berdasarkan hasil penelitian tindakan kelas (PTK) yang dilaksanakan di kelas V SD Negeri 002 Pasir Sialang diperoleh kesimpulan sebagai berikut. Proses perencanaan model pembelajaran kooperatif tipe Paired Story Telling pada keterampilan menulis karangan narasi pada keterampilan menulis karangan narasi di kelas V SD Negeri 002 Pasir Sialang yaitu: a) Guru membagi topik pelajaran menjadi dua bagian, b) Guru memberikan brainstorming mengenai topik yang akan dibahas, c) Peserta didik berkelompok secara berpasangan, d) Subtopik 1 diberikan kepada peserta didik pertama, dan peserta didik kedua menerima subtopik yang kedua, e) Peserta didik diminta untuk membaca bagiannya masing-masing dan mencatat beberapa informasi, kemudian peserta didik saling bertukar informasi, f) Masing-masing peserta didik berusaha untuk mengarang bagian lain berdasarkan informasi yang didapatkan, g) Kegiatan ini diakhiri mengenai topik dalam bahan pelajaran hari ini. 
Penggunaan model pembelajaran kooperatif tipe Paired Story Telling dapat meningkatkan keterampilan menulis karangan narasi pada peserta didik kelas $\mathrm{V}$ SD Negeri 002 Pasir Sialang. Hal ini dapat dibuktikan dari nilai prasiklus tentang menulis karangan narasi, diperoleh nilai rata-rata kelas 62. Pada siklus I dikenai tindakan yaitu guru menggunakan model kooperatif tipe Paired Story Telling sebagai model pembelajaran untuk meningkatkan keterampilan menulis karangan narasi dan terbukti rata-rata kelas menjadi 69,2. Pada siklus II rata-rata kelas keterampilan menulis karangan narasi mengalami peningkatan menjadi 78 .

\section{DAFTAR PUSTAKA}

Arikunto. (2010). Prosedur Penelitian Praktik (Edisi Revisi). Jakarta: Rineka Cipta.

Dalman. (2011). Keterampilan Menulis. Jakarta: Raja Grafindo Persada.

Fadhilaturrahmi, F. (2017a). Penerapan Pendekatan Saintifik Untuk Meningkatkan Kemampuan Komunikasi Matematik Peserta Didik di Sekolah Dasar. EDUHUMANIORA: Jurnal Pendidikan Dasar, 9(2), 109-118. https://doi.org/10/17509/EH.V912.7078

Huda, Miftahul. (2015). Cooperative Learning. Metode, Teknik, Struktur dan Model Penerapan. Yogyakarta: Pustaka Pelajar.

Isjoni. (2014). Cooperative Learning. Bandung: Alfabeta.

Isjoni. (2013). Cooperative Learning Efektifitas Pembelajaran Kelompok. Bandung: Alfabeta.

Iskandarwassid dan Dadang Sunendar. (2009). Strategi Pembelajaran Bahasa. Bandung: PT Remaja Rosdakarya.

Lie, Anita. (2014). Cooperative Learning. Jakarta: Grasindo.

Surya, Y. (2017). Penerapan Model Numbered Head Together untuk Meningkatkat Hasil Belajar Ips Kelas IV SD. Jurnal Review Pendidikan dan Pengajaran (JRPP).

Tarigan, H. G. (2013). Berbicara Sebagai Suatu Keterampilan Berbahasa. Bandung: CV Angkasa. 